\title{
Golden mussel (Limnoperna fortunei) in feed for broiler chicks using tannin as a sequestrant of toxic metals
}

\section{Mexilhão dourado (Limnoperna fortunei) na alimentação de pintos de corte utilizando tanino como sequestrante de metais tóxicos}

\author{
Douglas Fernando Bayerle ${ }^{1 *}$; Ricardo Vianna Nunes ${ }^{2}$; Affonso Celso \\ Gonçalves Junior ${ }^{2}$; Lucas Wachholz ${ }^{3}$; Carina Scherer ${ }^{4}$; Idiana Mara da Silva \\ Taciana Maria de Oliveira-Bruxel2; José Geraldo de Vargas Junior $^{5}$
}

\begin{abstract}
This study aimed to evaluate the use of wattle tannin as an adsorbent of toxic metals in broilers fed on diets with different levels of replacement of limestone with golden mussel meal. First, we conducted a trial to evaluate the performance of broiler chicks from 1 to 21 days old when fed on wattle tannin. For this we used 720 male broiler chicks that were one day old, in a completely randomized design with six treatments and six replications. The treatments were composed of basal diets with increasing levels of wattle tannin $(0,250,500,750,1000$ and $1250 \mathrm{~g}$ tonne- 1$)$, where the tannin replaced the inert material of the feed. All of the diets were isonutritive and isocaloric. The results showed that $250 \mathrm{~g}$ tonne- 1 of tannin was detrimental to weight gain, final weight and feed conversion, and the use of $1000 \mathrm{~g}$ tonne- 1 of wattle tannin, in addition to these effects, caused a drop in consumption of the ration. There was no effect of treatment on morphometric measurements of villi, crypt or the villus:crypt ratio. Next, we conducted a second test to evaluate the performance of broiler chicks from 1 to 21 days of age when fed with increasing levels of replacement $(0,25,50,75,100 \%)$ of limestone with golden mussel and even supplementation or not wattle tannin. Five repetitions were used and the birds were housed in a completely randomized design. In diets with the inclusion of tannin, $250 \mathrm{~g}$ tonne- 1 of wattle tannin was used, which replaced the inert material in the feed. In this test, 1200 male broiler chicks that were one day old were used. The results showed that the golden mussel contains large quantities of calcium, with low concentrations of toxic metals and microbiological contamination within the allowed range. Performance data show that mussel can be used to replace up to $100 \%$ of limestone in feed without affecting the variables, but the use of $250 \mathrm{~g}$ tonne- 1 of wattle tannin affects the performance of chicks. Bone quality was not changed by the treatments. Phosphorus and calcium in the bones remained stable during treatment and only the gray variation showed interaction effects from the use of mussel and wattle tannin.
\end{abstract}

Key words: Alternative food. Bone structure. Calcium. Intestinal morphology. Limestone. Performance.

\footnotetext{
${ }^{1}$ M.e em Zootecnia, Universidade Estadual do Oeste do Paraná, UNIOESTE, PPZ, Marechal Cândido Rondon, PR, Brasil. E-mail: douglas_fernandob@hotmail.com

2 Prof., UNIOESTE, Centro de Ciênicas Agrárias, CCA, Marechal Cândido Rondon, PR, Brasil. E-mail: nunesrv@hotmail.com; affonso133@hotmail.com

3 Pós-Graduando em Zootecnia, UNIOESTE, PPZ, Marechal Marechal Cândido Rondon, PR, Brasil. E-mail: lucaswach@hotmail. com; idianams@outlook.com

${ }^{4}$ Bolsista do PNPD, UNIOESTE, PPZ, Marechal Cândido Rondon, PR, Brasil. E-mail: carina_scherer@hotmail.com

${ }^{5}$ Prof., Universidade Federal do Espírito Santo, UFES, CCA, Alegre, ES, Brasil. E-mail: josegeraldovargas@yahoo.com.br

* Author for correspondence
} 


\section{Resumo}

Este estudo teve como objetivo avaliar a utilização de tanino de acácia como adsorvente de metais tóxicos em rações para pintos de corte alimentados com diferentes níveis de inclusão da farinha de mexilhão dourado em substituição ao calcário calcítico. Primeiramente foi realizado um ensaio para avaliar o desempenho de pintos de corte de 1 a 21 dias, alimentados com tanino de acácia, utilizandose 720 pintos de corte, machos, com um dia de idade, distribuídos em delineamento inteiramente casualizado, com seis tratamentos e seis repetições. Os tratamentos foram formados por rações basais com níveis crescentes de tanino de acácia $\left(0,250,500,750,1000,1250 \mathrm{~g}^{-1}{ }^{-1}\right.$ de tanino de acácia), onde o mesmo substituiu o material inerte da ração, sendo todas as dietas isonutritivas e isoenergéticas. Os resultados apontaram que $250 \mathrm{~g} \mathrm{ton}^{-1}$ de tanino foi prejudicial para ganho de peso, peso final e conversão alimentar, ao passo que, a utilização de $1000 \mathrm{~g} \mathrm{ton}^{-1}$ de tanino de acácia, além destes efeitos citados causou queda no consumo de ração. Para as medidas morfometricas de vilo, cripta e relação vilo:cripta, não houve efeitos dos tratamentos. Na sequência foi realizado um segundo ensaio para avaliar o desempenho de pintos de corte de 1 a 21 dias de idade com níveis crescentes de substituição $(0 ; 25 ; 50 ; 75 ; 100 \%)$ do calcário calcítico pelo mexilhão dourado e ainda a suplementação ou não de tanino de acácia, com 5 repetições, as aves foram alojadas em delineamento inteiramente casualizado. Nas dietas com a inclusão de tanino utilizou-se $250 \mathrm{~g} \mathrm{ton}^{-1}$ de tanino de acácia, o qual foi substituto do material inerte da ração. Foram utilizados neste ensaio 1200 pintos de corte, machos, com um dia de idade. Os resultados mostraram que o mexilhão dourado possui grande quantidade de cálcio, com baixas concentrações de metais tóxicos e contaminação microbiológica dentro da permitida. Os dados de desempenho demonstram que a utilização do mexilhão dourado pode ser realizada em até $100 \%$ de substituição ao calcário calcítico nas rações sem afetar as variáveis estudadas, porém a utilização de 250 $\mathrm{g}$ ton $^{-1}$ de tanino de acácia afeta o desempenho dos pintos de corte. A qualidade óssea não foi modificada pelos tratamentos. Os teores de fósforo e cálcio nos ossos permaneceram estáveis nos tratamentos, sendo que apenas a cinza apresentou variação interação nos efeitos pelo uso de mexilhão dourado e tanino de acácia.

Palavras-chave: Alimento alternativo. Calcário calcítico. Cálcio. Desempenho. Estrutura óssea. Morfometria intestinal.

\section{Introduction}

With the growth and modernization of the Brazilian poultry industry, there has been an increase in the production of poultry meat and consequently in the use of raw materials for the production of feed. To maintain this growth in feed production, nutritionists seek alternative sources that can replace the foods commonly used. The low cost of alternative ingredients is crucial for its use in the feed, as is the case for the meal obtained from the processing of mollusk valves. One of these mollusk species that is used in animal feed is the golden mussel, Limnoperna fortunei. It is composed mainly of calcium carbonate $\left(\mathrm{CaCO}_{3}\right)$, serving as a source of calcium for animals. As this species is not native to South America, it is considered exotic and invading, and has produced an environmental imbalance due to its high degree of infestation and proliferation, caused by its fast growth rate.
The use of $\mathrm{L}$. fortunei in diets can provide a calcium source for animals. However, because it is a filtering species, the golden mussel can be contaminated by toxic metals (MARENGONI et al., 2013). When ingested, these metals have accumulative effects in organisms and may cause serious health problems in humans. The use of tannin through the sequestering activity of the golden mussel could be an interesting practice to lessen the effects of toxic metals (HARIKISHORE et al., 2010) and enable the use of the golden mussel in poultry feed.

Thus, the aim of this experiment was to evaluate the use of tannin as an adsorbent of toxic metals in broiler chicks fed on diets with different levels of replacement of limestone in diets with golden mussel meal. 


\section{Material and Methods}

Two experiments were conducted at the experimental aviary of State University of West Parana - Unioeste, Campus of Marechal Cândido Rondon - PR.

To evaluate the amount of wattle tannin to be used in broiler chick diets, 720 male, 1-day old broiler chicks of Cobb 500 lineage were acquired from a commercial hatchery and vaccinated in the hatchery for the diseases Marek, Gumboro, Avian Bouba and Infectious Bronchitis.
The birds were distributed in a completely randomized design across 36 experimental units, which included six treatments and six replicates, with 20 birds in each. The average initial weight of the chicks was $42.5 \pm 0.47 \mathrm{~g}$.

The lighting program was 24 hours of light, and food and water were fed ad libitum. All diets were isonutritive and isocaloric, based on corn and soybean meal and formulated to meet the nutritional requirements for chicks of 1-21 days of age (Table 1). The treatments consisted of increasing levels of wattle tannin (tannin acid 72\%) at the concentrations: $0,250,500,750,1000$ and $1250 \mathrm{~g}$ ton- 1 of wattle tannin.

Table 1. Diet composition.

\begin{tabular}{lc}
\hline Ingredients (\%) & Initial \\
\hline Corn grain & 53.85 \\
Soybean meal & 37.00 \\
Degummed soy oil & 3.250 \\
Monocalcium phosphate & 1.713 \\
Limestone & 1.317 \\
Salt & 0.503 \\
DL-methionine 99\% & 0.308 \\
L-lysine.HCl 78\% & 0.212 \\
L-threonine 99\% & 0.052 \\
Vitamin suplement ${ }^{1}$ & 0.100 \\
Mineral suplement ${ }^{2}$ & 0.050 \\
Choline chloride 60\% & 0.060 \\
Antioxidant ${ }^{3}$ & 0.020 \\
Coxistac & 0.060 \\
Stafac 500 & 0.005 \\
Inert/Tannin & 1.500 \\
\hline Total & 100.00 \\
\hline Metabolizable Energy (kcal/kg) & Calculated composition \\
Crude Protein (\%) & 2960 \\
Digestible lysine (\%) & 21.40 \\
Digestible methyonine + cystin (\%) & 1.217 \\
Digestible threonine (\%) & 0.876 \\
Calcium (\%) & 0.791 \\
Available phosphorous (\%) & 0.920 \\
Sodium (\%) & 0.470 \\
\hline
\end{tabular}

${ }^{1}$ ROVIMIX - Vitamin suplement for poultry. Content: Vit A (min) 9000000 UI; Vit $\mathrm{D}_{3}(\min ) 2500000$ UI; Vit E (min) 20000 UI; Vit $\mathrm{K}_{3}(\mathrm{~min}) 2500 \mathrm{mg}$; Vit $\mathrm{B}_{1}(\mathrm{~min}) 1500 \mathrm{mg}$; Vit B $(\mathrm{min}) 6000 \mathrm{mg}$; Vit $\mathrm{B}_{6}(\mathrm{~min}) 3000 \mathrm{mg}$; Pantotenic acid (min) $12 \mathrm{~g}$; Niacin (min) $25 \mathrm{~g}$; Folic acid (min) $800 \mathrm{mg}$; Se (min) $250 \mathrm{mg}$; ${ }^{2}$ ROLIGOMIX - Mineral suplement for poultry. Content: $\mathrm{Cu}$ (min) $20 \mathrm{~g}$; $\mathrm{Fe}$ (min) 100g; Mn (min) 2000 mg; Zn (min) $100 \mathrm{~g} ;{ }^{3} \mathrm{BHT} ;{ }^{4}$ Salinomycin 12\%; ${ }^{5}$ Virginamycin. 
Environmental variables were measured twice a day, once in the morning and once in the afternoon, and the maximum and minimum values were recorded using a digital thermo-hygrometer that was installed near the birds. During the experimental period, the average temperature ranged between $24.25^{\circ} \mathrm{C}$ and $29.68^{\circ} \mathrm{C}$ and the relative humidity ranged from $42.48 \%$ to $63.76 \%$.

During the experimental period, dead birds were removed and the feed intake was recorded for corrections in intake and feed conversion ratio according to Sakomura and Rostagno (2007). At 21 days old, all birds and feed were weighed to determine weight gain (WG), feed intake (FI) and feed conversion rate (FCR).

At the end of the experiment, two birds per experimental unit $( \pm 5 \%$ average weight and starved for $8 \mathrm{~h}$ ) were slaughtered. A length of $4 \mathrm{~cm}$ from the distal duodenum was collected for morphometric analysis by microscopy, and histological sections were prepared according to Luna (1968). The image capture from the slides was carried out using an optical microscope with an image capture system. The villi and crypts were measured with an objective lens of $4 \mathrm{x}$ magnification. The height of villi was measured from the basal region to the top and the depth of crypts was the base to the transition region. The relationship of crypt:villi was calculated using the villus heights and crypt depths.

To evaluate the effect of wattle tannin on all variables studied, an analysis of variance followed by a Dunnett's test was performed, using the basal diet as a control. Subsequently, polynomial regression analysis was used to assess the effect of increasing levels of wattle tannin on all variables. Significance of results was judged using the 5\% level of probability and analyses were performed using the Statistical and Genetics Analysis System - SAEG (UNIVERSIDADE FEDERAL VIÇOSA, UFV, 1999).

In the second experiment, 1200 male, 1-day old broiler chicks of the Cobb 500 lineage were used.
The birds were individually weighed and were found to have an average weight of $46.02 \pm 0.17 \mathrm{~g}$. They were evenly distributed across 50 experimental units, with 24 birds each, housed in a completely randomized design. A 2 × 5 factorial scheme was used, where the first factor was the supplementation or not of wattle tannin (tannic acid) and the second factor was the increasing replacement levels $(0,25$, $50,75,100 \%$ ) of the limestone in the feed by golden mussel meal, with five replicates per treatment.

The golden mussel was collected at the Itaipu Binacional reservoir, in the municipality of Santa Helena - PR, by using floating net cages. The mussels were exposed to the sun for drying, then bagged and stored.

The golden mussels were milled using a hammer mill type and the following components of the samples of meal were determined: dry matter, crude protein, mineral matter (SILVA; QUEIROZ, 2006), chromium $(\mathrm{Cr})$, cadmium $(\mathrm{Cd})$, lead $(\mathrm{Pb})$, calcium $(\mathrm{Ca})$ and phosphorus $(\mathrm{P})$. To quantify $\mathrm{Cr}$, $\mathrm{Cd}, \mathrm{Pb}$ and $\mathrm{Ca}$, nitropercloric digestion (AOAC, 2005) and atomic absorption spectrometry modality flame (AAS-flame) were used. ultraviolet-visible spectroscopy (UV-Vis) was used to quantify P. Microbiological analysis for coliforms and Salmonella sp. in the golden mussel was performed in the Microbiology Laboratory, according to the methodology described by Silva et al. (1997). The diets were formulated to meet the nutritional requirements of the birds and $250 \mathrm{~g}$ ton- 1 of wattle tannin was used; this quantity was determined in the first trial (Table 2).

Environmental variables were measured twice a day, in the morning and afternoon, and the points of maximum and minimum values were recorded using a digital thermo-hygrometer that was installed near the birds. During this experimental period, the average temperature ranged between $22.60^{\circ} \mathrm{C}$ and $25.00^{\circ} \mathrm{C}$ and the relative humidity ranged from $46.33 \%$ to $55.04 \%$.

The birds and feed were weighed at the beginning 
and at the end of the experiment to assess WG, FI and FCR. At the end of the trial period, two birds per experimental unit were slaughtered to collect the breast, thigh, liver and kidneys. The breast and the thigh were deboned to obtain the breast meat and the tibia bone. The left tibia was weighed and the length measured using a digital caliper, and these measurements were used to calculate the Seedor Index. Bone strength was determined using
CT3 texture analyzer equipment from Brookfield. The organs (liver and kidneys), the breast meat and the right tibia were dried in a forced ventilation oven at $55^{\circ} \mathrm{C}$, milled and then chemically analyzed in order to quantify $\mathrm{Ca}, \mathrm{P}, \mathrm{Cr}, \mathrm{Cd}$ and $\mathrm{Pb}$ using same methodology previously described for the analysis of these minerals in the mussel. The analysis of $\mathrm{Ca}$ and $\mathrm{P}$ were performed only for the tibia. The methodology described by Silva and Queiroz (2006) was used to determine dry matter and mineral matter.

Table 2. Experimental diets composition.

\begin{tabular}{|c|c|c|c|c|c|}
\hline & \multicolumn{5}{|c|}{ Replacement level (\%) of the limestone by golden mussel } \\
\hline Ingredients (\%) & 0 & 25 & 50 & 75 & 100 \\
\hline Corn grain & 53.51 & 53.46 & 53.36 & 53.24 & 53.13 \\
\hline Soybean meal & 39.33 & 39.32 & 39.33 & 39.36 & 39.38 \\
\hline Degummed soy oil & 2.500 & 2.506 & 2.540 & 2.582 & 2.620 \\
\hline Monocalcium phosphate & 1.900 & 1.900 & 1.900 & 1.900 & 1.900 \\
\hline Limestone & 0.912 & 0.684 & 0.456 & 0.228 & 0.000 \\
\hline Golden mussel & 0.000 & 0.282 & 0.563 & 0.844 & 1.126 \\
\hline Salt & 0.508 & 0.508 & 0.508 & 0.508 & 0.508 \\
\hline DL-methionine $99 \%$ & 0.360 & 0.360 & 0.360 & 0.360 & 0.360 \\
\hline L-lysine. $\mathrm{HCl}$ 78\% & 0.272 & 0.273 & 0.272 & 0.272 & 0.272 \\
\hline L-threonine $99 \%$ & 0.097 & 0.097 & 0.097 & 0.097 & 0.097 \\
\hline $\mathrm{L}$ - valine $99 \%$ & 0.068 & 0.068 & 0.068 & 0.068 & 0.068 \\
\hline Vitamin suplement $^{1}$ & 0.100 & 0.100 & 0.100 & 0.100 & 0.100 \\
\hline Mineral suplement ${ }^{2}$ & 0.050 & 0.050 & 0.050 & 0.050 & 0.050 \\
\hline Choline chloride $60 \%$ & 0.060 & 0.060 & 0.060 & 0.060 & 0.060 \\
\hline Coxistac $^{3}$ & 0.060 & 0.060 & 0.060 & 0.060 & 0.060 \\
\hline Antioxidant ${ }^{4}$ & 0.020 & 0.020 & 0.020 & 0.020 & 0.020 \\
\hline Stafac $500^{5}$ & 0.005 & 0.005 & 0.005 & 0.005 & 0.005 \\
\hline Inert (washed sand) & 0.250 & 0.250 & 0.250 & 0.250 & 0.250 \\
\hline \multirow[t]{2}{*}{ Total } & 100.00 & 100.00 & 100.00 & 100.00 & 100.00 \\
\hline & \multicolumn{5}{|c|}{ Calculated composition } \\
\hline Metabolizable Energy (kcal/kg) & 2961 & 2960 & 2960 & 2960 & 2960 \\
\hline Crude Protein (\%) & 22.62 & 22.62 & 22.62 & 22.62 & 22.62 \\
\hline Digestible lysine (\%) & 1.324 & 1.324 & 1.324 & 1.324 & 1.325 \\
\hline Digestible methyonine + cystin $(\%)$ & 0.953 & 0.953 & 0.953 & 0.953 & 0.953 \\
\hline Digestible threonine $(\%)$ & 0.861 & 0.861 & 0.861 & 0.861 & 0.861 \\
\hline Digestible valine $(\%)$ & 1.020 & 1.020 & 1.020 & 1.020 & 1.020 \\
\hline Calcium $(\%)$ & 0.920 & 0.920 & 0.920 & 0.920 & 0.920 \\
\hline Available phosphorous (\%) & 0.470 & 0.470 & 0.470 & 0.470 & 0.470 \\
\hline Sodium $(\%)$ & 0.220 & 0.220 & 0.220 & 0.220 & 0.220 \\
\hline
\end{tabular}

${ }^{1}$ ROVIMIX - Vitamin suplement for poultry. Content: Vit A (min) 9000000 UI; Vit D $(\min ) 2500000$ UI; Vit E (min) 20000 UI; Vit $\mathrm{K}_{3}$ (min) $2500 \mathrm{mg}$; Vit $\mathrm{B}_{1}$ (min) $1500 \mathrm{mg}$; Vit B (min) $6000 \mathrm{mg}$; Vit B (min) 3000 mg; Pantotenic acid (min) 12 g; Niacin (min) $25 \mathrm{~g}$; Folic acid (min) $800 \mathrm{mg}$; Se (min) $250 \mathrm{mg} ;{ }^{2} \mathrm{ROLIGOMIX} \mathrm{-} \mathrm{Mineral} \mathrm{suplement} \mathrm{for} \mathrm{poultry.} \mathrm{Content:} \mathrm{Cu} \mathrm{(min)} \mathrm{20g;} \mathrm{Fe} \mathrm{(min)}$ 100g; Mn (min) $2000 \mathrm{mg}$; Zn (min) $100 \mathrm{~g} ;{ }^{3}$ Salinomycin 12\%; ${ }^{4} \mathrm{BHT} ;{ }^{55}$ Virginamycin. 
Performance results, presence of toxic metals and bone characteristics (bone strength and Seedor index) were statistically evaluated using analysis of variance to verify the effects of limestone replacement levels with golden mussel meal using polynomial regression at a 5\% significance level, and to evaluate the effect of wattle tannin the F test was applied at a 5\% significance level. Analyses were conducted using the Statistical and Genetics Analysis System - SAEG (UNIVERSIDADE FEDERAL VIÇOSA, UFV, 1999).

\section{Results and Discussion}

In the first experiment, 1- to 21-day old birds fed with 1000 and $1250 \mathrm{~g}$ ton- 1 of wattle tannin showed significantly lower FI compared to the control diet (Dunett's test at 5\% probability; Table 3). The effect of tannin level on FI was quadratic, with higher FI $(1191.71 \mathrm{~g})$ at the level of $367.21 \mathrm{~g}$ ton-1 of wattle tannin. These values were obtained through the derivation of adjusted regression equations for the variable.

Table 3. Performance of broilers from 1 to 21 days old fed different levels of tannin.

\begin{tabular}{|c|c|c|c|c|}
\hline Tannin $\left(\mathrm{g}\right.$ ton $\left.^{-1}\right)$ & Feed intake $(\mathrm{g})$ & Final weight $(\mathrm{g})$ & Weight gain $(\mathrm{g})$ & Feed conversion rate $(\mathrm{g} / \mathrm{g})$ \\
\hline 0 (control) & $1160.34^{a}$ & $802.07^{\mathrm{a}}$ & $759.89^{a}$ & $1.527^{\mathrm{a}}$ \\
\hline 250 & $1183.87^{a}$ & $776.17^{\mathrm{b}}$ & $733.19^{b}$ & $1.615^{\mathrm{b}}$ \\
\hline 500 & $1195.70^{a}$ & $747.67^{\mathrm{b}}$ & $705.33^{\mathrm{b}}$ & $1.695^{\mathrm{b}}$ \\
\hline 750 & $1152.49^{a}$ & $709.86^{\mathrm{b}}$ & $667.47^{\mathrm{b}}$ & $1.727^{\mathrm{b}}$ \\
\hline 1000 & $1078.33^{\mathrm{b}}$ & $650.78^{\mathrm{b}}$ & $607.83^{\mathrm{b}}$ & $1.775^{\mathrm{b}}$ \\
\hline 1250 & $990.30^{\mathrm{b}}$ & $620.40^{\mathrm{b}}$ & $578.08^{\mathrm{b}}$ & $1.713^{\mathrm{b}}$ \\
\hline LSD & 37.05 & 20.79 & 20.61 & 0.039 \\
\hline \multirow[t]{2}{*}{ CV $(\%)$} & 2.444 & 2.153 & 2.269 & 1.732 \\
\hline & \multicolumn{4}{|c|}{ Probability } \\
\hline Linear & $<0.001$ & $<0.001$ & $<0.001$ & $<0.001$ \\
\hline Quadratic & $<0.001$ & 0.327 & 0.312 & $<0.001$ \\
\hline \multicolumn{3}{|c|}{ Regression equations } & & $\mathrm{R}^{2}$ \\
\hline Feed intake & \multicolumn{3}{|c|}{$1156.17+0.193600 \mathrm{X}-0.000263607 \mathrm{X}^{2}$} & 0.89 \\
\hline Final weight & \multicolumn{3}{|c|}{$823.500-0.163367 \mathrm{X}$} & 0.92 \\
\hline Weight gain & \multicolumn{3}{|c|}{$780.698-0.163091 X$} & 0.92 \\
\hline Feed conversion rate & \multicolumn{3}{|c|}{$1.48774+0.000570719 X-0.000000307 X^{2}$} & 0.71 \\
\hline
\end{tabular}

At 21 days old, there was a linear relationship between final weight (FW) and WG. The inclusion of tannin had a significantly negative effect on both of these characteristics (Dunnett's test at 5\% probability), resulting in decreased performance. Similarly, the FCR exhibited a quadratic response with maximum conversion (2.134) at the level of $929.51 \mathrm{~g}$ of tannin ton $^{-1}$ of feed, also featuring a reduction in performance.

Torres et al. (2013) evaluated diets containing sorghum tannin and noted that replacing up to
$100 \%$ of the low-tannin sorghum with corn did not influence the WG, FI or FCR in broiler chicks up to 21 days old. They also reported that a concentration of up to $2.6 \mathrm{~g} \mathrm{~kg}^{-1}$ of tannins in the diet did not significantly affect the performance of broiler chickens, but in this experiment, it was possible to note a reduction in broiler performance with the maximum tannin concentration of $0.9 \mathrm{~g} \mathrm{~kg}^{-1}$.

Moyle et al. (2012) observed that when fed on increasing levels of Sericea lespedeza, a grass rich in tannin, poultry decreased in weight in the second 
and third week of life, and showed an increase in FI and consequently worsening FCR. This decline in performance is related to ingredients with low nutrient levels in the diet, such as tannins. They cause reductions in growth due to their toxicity and their negative impact on nitrogen retention and use of amino acids by the body, due to a decrease in protein digestibility.

The decline in performance may also be related to hypertrophy of the pancreas, which can change the production and levels of trypsinogen and alphaamylase. This is turn influences the action of trypsin and alpha-amylase in the duodenum and jejunum and can cause liver hyperplasia, which impairs regulatory functions, such as detoxification of the body, bile production, synthesis, storage and breakdown of glycogen, cholesterol synthesis, and conversion of ammonia to urea (NELSON; COX, 2008).

The morphometric analysis of histological sections of the duodenum at 21 days old revealed no significant effect $(\mathrm{P}>0.05)$ of tannin on villus height, crypt depth, or the relationship of villus:crypt (Table 4).

Table 4. Duodenum intestinal morphometry of broilers at $21 \mathrm{~d}$-old fed diets with different inclusion levels of tannin.

\begin{tabular}{cccc}
\hline Tannin $\left(\mathrm{g} \mathrm{ton}^{-1}\right)$ & Villus height $(\mu \mathrm{m})$ & Crypt depth $(\mu \mathrm{m})$ & Relation Villus height:Crypt depth \\
\hline 0 & 1364.00 & 115.93 & 12.19 \\
250 & 1554.43 & 121.03 & 13.11 \\
500 & 1577.13 & 125.14 & 13.02 \\
750 & 1397.97 & 137.60 & 10.34 \\
1000 & 1617.42 & 134.34 & 12.60 \\
1250 & 1528.66 & 142.13 & 11.42 \\
CV $(\%)$ & 13.721 & 21.476 & 23.854 \\
\hline & \multicolumn{3}{|}{ Probability } \\
\hline Linear & 0.965 & 0.164 & 0.315 \\
Quadratic & 0.564 & 0.845 & 0.560 \\
\hline
\end{tabular}

$\mathrm{CV}=$ Coefficient of variation (\%).

Similar data were observed by Garcia et al. (2005), whereby there was no significant effect of replacing corn with high or low tannin sorghum on the length of the duodenum, jejunum or ileum. Torres et al. (2013) noted the same, also finding no significant effect on the cell growth of duodenal crypt, villus height or crypt depth in broiler chicks fed diets containing 0,50 or $100 \%$ low-tannin sorghum in replacement of corn. On the other hand, these authors observed significant changes in the intestinal mucosa of broilers fed diets containing sorghum; namely increased mitotic index and loss of epithelium.

The integrity of the membrane and epithelial enzymes is essential to ensure the digestion and absorption of nutrients from the intestinal lumen.
According to Gonçalves et al. (2014), the condensed tannins may decrease the absorption of nutrients through the intestinal wall due to metabolic phenomena that inhibit the action of enzymes present in the digestive system. Nyamambi et al. (2007) observed that villus height and crypt depth of the duodenum decreased with increasing tannin levels in the diet. Moreover, Torres et al. (2013) observed reduced aminopeptidase activity in the jejunum. This enzyme is responsible for almost all peptidase activity on the jejunum and ileum brush border. However, this reduction did not reduce the birds' performance.

The calcium level in the golden mussel (Table 5) was $30.55 \%$, which was higher than that found by Almeida et al. (2006), who observed 15.91\% Ca 
in mussel meal, but similar to that found by Canzi (2011), who observed mean values of $27.27 \% \mathrm{Ca}$ and $28.70 \% \mathrm{Ca}$ in whole mussels and mussel valves meal, respectively. The chemical composition of golden mussel is similar to other calcium sources, such as oyster meal. According Çath et al. (2012) oyster meal contained $38.90 \%$ calcium, and a study by Silva Fernandes and Peixoto (2000) reported values of $36.60 \%$ calcium.

Canzi (2011) assessed the use of golden mussel meal to fish and found that Limnoperna fortunei contained $12.95 \%$ crude protein and Almeida et al. (2006) reported values of $7.38 \%$ crude protein. These two values are higher than that found in this experiment, which was $0.50 \%$. Even as the first author, the quantity of mineral matter was $80.53 \%$, which was similar to the value of $87.60 \%$ found in this study, showing that this mollusk contains a high concentration of minerals. The value of potassium found by Canzi (2011) was $1.73 \%$, which was close to the value of $1.63 \%$ observed in this study. For other minerals, there were discrepancies between the values found by Canzi (2011) and those in this study: phosphorus and zinc were found to have values of 0.11 and $15 \mathrm{mg} \mathrm{g}^{-1}$ respectively (CANZI, 2011), while in this experiment, observed values were 0.38 and $79 \mathrm{mg} \mathrm{g}^{-1}$, respectively. This difference found in the mineral values was probably due to the environment from which these mollusks were collected.

Table 5. Chemical composition and levels of toxic metals of the golden mussel.

\begin{tabular}{ccccccc}
\hline $\begin{array}{c}\text { Dry matter } \\
(\%)\end{array}$ & $\begin{array}{c}\text { Ash } \\
(\%)\end{array}$ & $\begin{array}{c}\text { Crude protein } \\
(\%)\end{array}$ & $\begin{array}{c}\text { Calcium } \\
(\%)\end{array}$ & $\begin{array}{c}\text { Phosphorus } \\
(\%)\end{array}$ & Potassium (\%) & $\begin{array}{c}\text { Magnesium } \\
(\%)\end{array}$ \\
\hline 98.11 & 87.60 & 0.50 & 30.55 & 0.38 & 1.63 & 0,37 \\
\hline Zinc $\left(\mathrm{mg} \mathrm{g}^{-1}\right)$ & Manganese $\left(\mathrm{mg} \mathrm{g}^{-1}\right)$ & Iron $\left(\mathrm{mg} \mathrm{g}^{-1}\right)$ & Cadmium $\left(\mathrm{mg} \mathrm{g}^{-1}\right)$ & $\begin{array}{c}\text { Chromium } \\
\left(\mathrm{mg} \mathrm{g}^{-1}\right)\end{array}$ & Lead $\left(\mathrm{mg} \mathrm{g}^{-1}\right)$ \\
\hline 79.00 & 311.00 & 1520.00 & $<0.005$ & $<0.001$ & 0.46 \\
\hline
\end{tabular}

The concentration of toxic metals such as cadmium and chromium in the golden mussel meal was within the limits allowed by Brazilian law. The lead concentration was the highest $\left(0.46 \mathrm{mg} \mathrm{g}^{-1}\right)$, but still remained within the maximum permitted $\left(2.00 \mathrm{mg} \mathrm{g}^{-1}\right)$. Although the concentrations were found to be within the limits allowed by law, the cumulative effect of toxic metals can be a problem when consumed in large quantities. The low concentrations of toxic metals in the golden mussel can be explained by the fact that the mussels were collected at the surface of the water column. According to Ferreira et al. (2010) and Marengoni et al. (2013), the concentrations of metals in sediments are greater than those found in the water column. However, these toxic metal particles are available to organisms such as the golden mussel, and some characteristics may facilitate this process such as particle size, type of metal ion, organic content and metal concentrations present in the water.

The quantity of coliforms was found to be lower than 0.4 MPN g-1, which is within acceptable levels. No contamination by Salmonella sp. was found, indicating that the golden mussel meal was not microbiologically contaminated beyond the permitted limits. Some authors evaluated the presence of other possible microbiological contaminants in the golden mussel, finding values less than 1.0 CFU $\mathrm{g}^{-1}$ for enterobacteria and 2.4

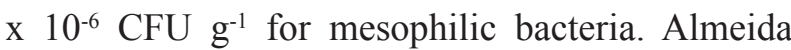
et al. (2006) observed values less than $10 \mathrm{CFU}$ $\mathrm{g}^{-1}$ for coliforms at $45^{\circ} \mathrm{C}$ and less than $10^{2} \mathrm{CFU}$ $\mathrm{g}^{-1}$ for Salmonella sp., however, the presence of Staphylococcus aureus was not found.

The performance results for chicks from 1 to 21 days old showed no interaction $(\mathrm{P}<0.05)$ between 
the use of tannin and the level of replacement with golden mussel (Table 6). Golden mussel can be used as a source of calcium for broilers from 1 to 21 days old by replacing limestone in feed by up to $100 \%$ without affecting FI, WG, FCR and viability. For FW, WG, FI and FCR, there was no interaction between the calcium source substitution level and the diet inclusion of tannin $(\mathrm{P}>0.05)$. However, analysis of variance indicated that in isolation, the tannin addition significantly decreased FW, WG, FI $(\mathrm{P}<0.05)$, and consequently worsened the FCR ( $\mathrm{P}$ $<0.05)$.

According to Melo and Moura (2009), higher solubility of $\mathrm{Ca}$ sources improves bioavailability and intestinal absorption of $\mathrm{Ca}$. They also emphasize that organic sources of this mineral (such as seaweed, shells, bones and eggshell) present higher solubility compared to inorganic sources
(MELO; MOURA, 2009). Despite this, inorganic sources are the most commonly used in animal feed because they are abundant and inexpensive, such as limestone and dicalcium phosphate. In this context, the performance of $\mathrm{Ca}$ from golden mussels in this experiment was satisfactory, indicating that the tested absorption rates were sufficient to meet the metabolic demands of birds at this stage. This hypothesis is supported by the fact that the birds possess the ability to regulate the use of $\mathrm{Ca}$ to meet their physiological needs (PINTO et al., 2010). Other factors studied here, such as FI, also suggest that the amount of calcium in the golden mussel was inline with the requirements of the animals, because according to Mello et al. (2012), a diet that is deficient in this mineral causes increased FI, whereas excess $\mathrm{Ca}$ could result in a reduction in FI, due to the low palatability of $\mathrm{Ca}$.

Table 6. Performance of broilers from 1 to 21 days old fed diets with diferentes levels of replacement of limestone by golden mussel, with or without tannin addition.

\begin{tabular}{|c|c|c|c|c|c|c|c|c|}
\hline \multirow{3}{*}{ Inclusion level } & Final $\mathrm{w}$ & ght (g) & \multicolumn{2}{|c|}{ Weight gain $(\mathrm{g})$} & \multicolumn{2}{|c|}{ Intake $(\mathrm{g})$} & \multicolumn{2}{|c|}{ Feed conversion rate $(\mathrm{g} / \mathrm{g})$} \\
\hline & \multicolumn{8}{|c|}{ Tannin } \\
\hline & No & Yes & No & Yes & No & Yes & No & Yes \\
\hline 0 & 840.56 & 814.58 & 794.51 & 768.73 & 1149.12 & 1141.29 & 1.446 & 1.485 \\
\hline 25 & 881.59 & 814.22 & 835.61 & 768.12 & 1205.30 & 1140.11 & 1.443 & 1.484 \\
\hline 50 & 833.33 & 809.90 & 787.38 & 764.02 & 1131.71 & 1123.54 & 1.437 & 1.471 \\
\hline 75 & 869.58 & 815.42 & 823.58 & 769.28 & 1180.50 & 1124.00 & 1.433 & 1.461 \\
\hline 100 & 830.80 & 820.42 & 784.71 & 774.27 & 1135.82 & 1133.54 & 1.448 & 1.464 \\
\hline \multirow[t]{2}{*}{ Mean } & $851.17^{\mathrm{a}}$ & $814.91^{\mathrm{b}}$ & $805.16^{\mathrm{a}}$ & $768.87^{\mathrm{b}}$ & $1160.49^{\mathrm{a}}$ & $1132.50^{\mathrm{b}}$ & $1.442^{\mathrm{a}}$ & $1.473^{\mathrm{b}}$ \\
\hline & & \multicolumn{7}{|c|}{ Probability } \\
\hline Tannin & \multicolumn{2}{|c|}{$<0.01$} & \multicolumn{2}{|c|}{$<0.01$} & \multicolumn{2}{|c|}{0.012} & \multicolumn{2}{|r|}{$<0.01$} \\
\hline Golden mussel & \multicolumn{2}{|c|}{0.140} & \multicolumn{2}{|c|}{0.141} & \multicolumn{2}{|c|}{0.091} & \multicolumn{2}{|r|}{0.211} \\
\hline Interaction & \multicolumn{2}{|c|}{0.121} & \multicolumn{2}{|c|}{0.118} & \multicolumn{2}{|c|}{0.188} & \multicolumn{2}{|r|}{0.617} \\
\hline CV $(\%)$ & \multicolumn{2}{|c|}{3.210} & \multicolumn{2}{|c|}{3.392} & \multicolumn{2}{|c|}{3.276} & \multicolumn{2}{|r|}{1.304} \\
\hline
\end{tabular}

${ }^{\mathrm{a}, \mathrm{b}}$ Values followed by different letters in the same line differs on $\mathrm{F}$ test at the $5 \%$ level of significance; $\mathrm{CV}=\mathrm{Coefficient}$ of variation $(\%)$.

The use of wattle tannin at a concentration of $250 \mathrm{~g} \mathrm{ton}^{-1}$ of ration caused a reduction in FI $(\mathrm{P}<$ $0.05)$, and hence a decrease in weight $(\mathrm{P}<0.05)$. This reduction was probably due to the effect of tannin on digestibility, which then reduces the WG and negatively affects the FCR $(\mathrm{P}<0.05)$. The causes of alterations in the performance of birds due to tannin in their diets include: decreased food palatability and voluntary intake, digestibility of proteins, carbohydrates, starch and lipids, and the inhibition of certain enzymes in the gastrointestinal tract, hindering the absorption of nutrients. 
The values of the Seedor index and bone strength (kgf) of broiler chickens at 1 to 21 days old were not affected $(\mathrm{P}>0.05)$ by the studied factors (Table 7). These results demonstrate that $100 \%$ inclusion of golden mussel can be used as a source of $\mathrm{Ca}$ for broilers from 1 to 21 days old without affecting their bone development. Differences in Seedor index and bone strength were not observed. This result allows us to affirm that the use of golden mussel and tannin in diets of broilers did not cause the bones to suffer calcification problems.

The main $\mathrm{Ca}$ reserve of chickens is in their bones, accounting for $98-99 \%$ of this mineral in the body (SAKOMURA et al., 2014). When Ca concentration in the blood decreases, $\mathrm{Ca}$ from bones is mobilized to raise the levels in the blood. This loss of $\mathrm{Ca}$ results in decalcification and weakening of bones. Other characteristics may demonstrate symptoms of calcium deficiency in birds, such as rickets, which produces characteristic swollen joints, enlargement of bone ends and rubberized beaks, due to poor deposition of $\mathrm{Ca}$ in these structures (SAKOMURA et al., 2014). According to these authors, osteomalacia is another indication of Ca deficiency that can compromise the development of older birds. However, in this study, none of these symptoms were observed.

Table 7. Seedor index and bone strength of broilers from 1 to 21 days old fed diets with differents levels of replacement of limestone by golden mussel, with or without tannin adition.

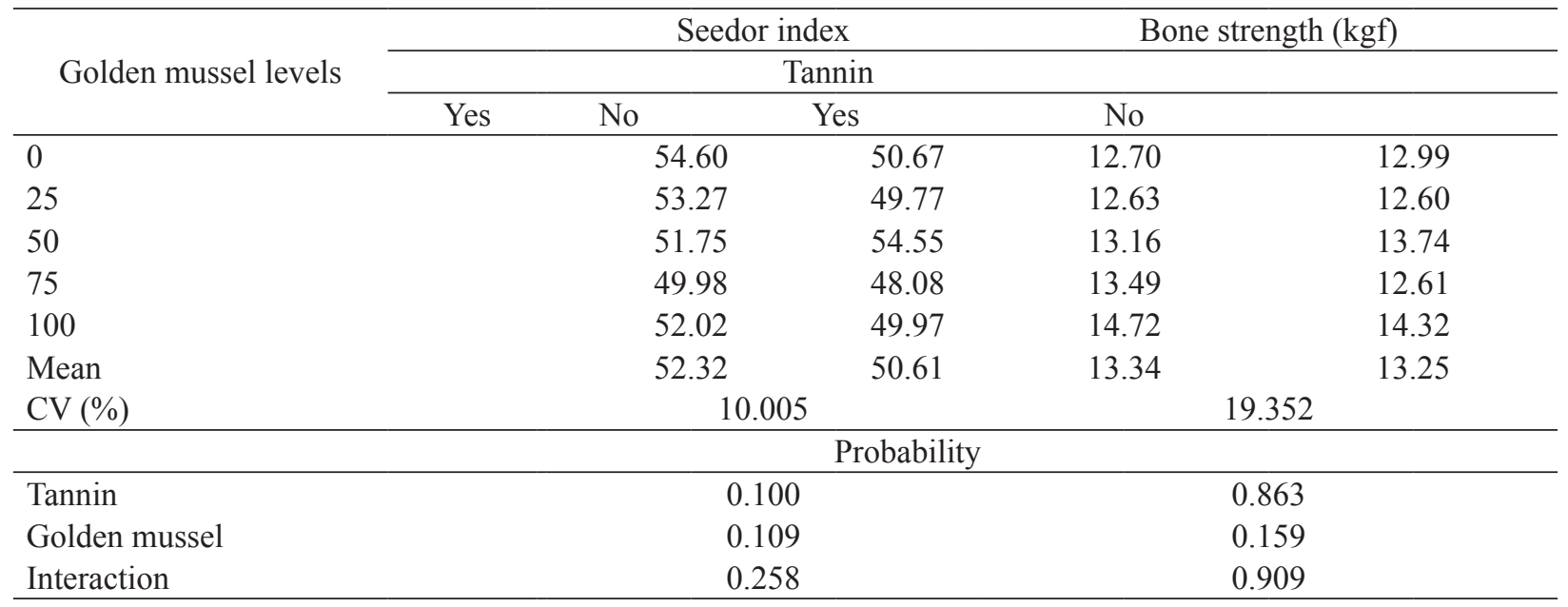

$\mathrm{CV}=$ Coefficient of variation (\%).

The results of $\mathrm{P}, \mathrm{Ca}$ and mineral matter in bones (Table 8) demonstrate that there was an interaction between factors $(\mathrm{P}<0.05)$ for mineral matter. By breaking down the data and evaluating the effect of limestone replacement by golden mussel into isolated factors, it was observed that, regardless of the studied factors, there was no significant adjustment of the models. These results demonstrate that the availability of $\mathrm{Ca}$ and $\mathrm{P}$ in the diets did not affect the deposition of $\mathrm{Ca}, \mathrm{P}$ and mineral matter in the bones of the birds in the initial phase.
Calcium homeostasis is influenced by the production of parathormone, calcitonin and renal hydrolase for the activation of cholecalciferol, which acts on intestinal absorption and metabolic utilization (NELSON; COX, 2008). According to Macari et al. (2002), this homeostatic mechanism has an important function in preventing excessive absorption or toxicity of $\mathrm{Ca}$ in birds. The calcium concentration of bones undergoes a dynamic process of mineralization due to remodeling and renewal processes in the plasma. The balancing of Ca levels in the plasma is fundamental because it can be 
absorbed and used for the growth of chickens, i.e. it is needed for satisfactory bone mineralization for structural development of the animals.

Incidence of toxic metals $(\mathrm{Cd}, \mathrm{Cr}$ and $\mathrm{Pb})$ was not detected in breast meat, tibia bones or organs (liver and kidneys), showing that the contamination by toxic metals in feed (derived from the golden mussel) was not high enough to transfer to the poultry meat. This is likely due to the low concentrations of these heavy metals found in the golden mussel, providing a satisfactory result for the consumption of these birds.

Table 8. Calcium and phosphorus levels in bones of broilers from 1 to 21 days old fed diets with differents levels of replacement of limestone by golden mussel, with or without tannin adition.

\begin{tabular}{|c|c|c|c|c|c|c|}
\hline \multirow{3}{*}{$\begin{array}{c}\text { Golden mussel } \\
\text { levels }\end{array}$} & \multicolumn{2}{|c|}{ Phosphorus (\%) } & \multicolumn{2}{|c|}{ Calcium (\%) } & \multicolumn{2}{|c|}{ Ash (\%) } \\
\hline & \multicolumn{5}{|c|}{ Tannin } & \multirow[b]{2}{*}{ No } \\
\hline & Yes & No & Yes & No & Yes & \\
\hline 0 & 2.27 & 2.30 & 17.79 & 17.90 & 44.94 & 46.35 \\
\hline 25 & 2.28 & 2.28 & 18.00 & 18.26 & 47.08 & 45.94 \\
\hline 50 & 2.28 & 2.29 & 18.13 & 18.27 & 46.81 & 46.30 \\
\hline 75 & 2.29 & 2.26 & 19.14 & 18.38 & 46.81 & 47.79 \\
\hline 100 & 2.24 & 2.27 & 17.67 & 18.16 & 46.29 & 48.00 \\
\hline Mean & 2.27 & 2.28 & 18.15 & 18.19 & 46.39 & 46.88 \\
\hline CV (\%) & \multicolumn{2}{|c|}{2.843} & \multicolumn{2}{|c|}{13.397} & \multicolumn{2}{|c|}{3.092} \\
\hline \multicolumn{7}{|c|}{ Probability } \\
\hline Tannin & \multicolumn{2}{|c|}{0.504} & \multicolumn{2}{|c|}{0.921} & \multicolumn{2}{|c|}{0.092} \\
\hline Golden mussel & \multicolumn{2}{|c|}{0.434} & \multicolumn{2}{|c|}{0.779} & \multicolumn{2}{|c|}{0.004} \\
\hline Interaction & \multicolumn{2}{|c|}{0.621} & \multicolumn{2}{|c|}{0.943} & \multicolumn{2}{|c|}{0.007} \\
\hline
\end{tabular}

$\mathrm{CV}=$ Coefficient of variation (\%).

\section{Conclusions}

The use of tannin to sequester heavy metals in the golden mussel adversely affects the performance of chicks. The golden mussel can be used as a source of $\mathrm{Ca}$ for broiler chicks from 1 to 21 days old. It does not alter the development, intestinal morphology or the bones of the birds, and the use of this ingredient does not contaminate broiler chickens with toxic heavy metals.

\section{References}

ALMEIDA, H. C.; SUSZEK, A. P. C.; MENDONÇA, S. N. T. G. C.; FLAUZINO, R. S. Estudo do Limnoperna fortunei (mexilhão dourado) como ingrediente na ração animal, através de características físico-químicas, microbiológicas e presença de mercúrio. Higiene Alimentar, São Paulo, v. 20, n. 145, p. 61-65, 2006.
ASSOCIATION OF OFFICIAL ANALYTICAL CHEMISTS - AOAC. Official methods of analysis of the association analytical chemists. $18^{\text {th }}$ ed. Gaithersburg: AOAC International, 2005.

CANZI, C. Avaliação da utilização do mexilhão dourado (Limnoperna fortunei Dunker, 1857) na elaboração de farinha para alimentação da tilápia (Oreochromis Niloticus Linnaeus, 1758). 2011. Dissertação (Mestrado em Recursos Pesqueiros e Engenharias de Pesca) Universidade Estadual do Oeste do Paraná, Toledo.

ÇATH, A. U.; BOZKURT, M.; KÜÇÜKYILMAZ, K.; CMAR, M.; BINTAS, E.; COVEN, F.; ATIK, H. Performance and egg quality of aged laying hens fed diets supplemented with meat and bone meal or oyster shell meal. South African Journal of Animal Science, Hatfield, v. 42, n. 1, p. 74-82, 2012.

FERREIRA, A. P.; HORTA, M. A. P.; CUNHA, C. L. N. da. Avaliação das concentrações de metais pesados no sedimento, na água e nos órgãos de Nycticorax nycticorax (Garça-da-noite) na Baía de Sepetiba, RJ, Brasil. Revista da Gestão Costeira Integrada, Lisboa, v. 10, n. 2, p. 229241, 2010. 
GARCIA, R. G.; MENDES, A. A.; ANDRADE, C. D.; PAZ, I. C. L. A.; TAKAHASHI, S. E.; PELÍCIA, K.; KOMIYAMA, C. M.; QUINTEIRO, R. R. Avaliação do desempenho e de parâmetros gastrintestinais de frangos de corte alimentados com dietas formuladas com sorgo alto tanino e baixo tanino. Ciência e Agrotecnologia, Lavras, v. 29, n. 6, p. 1248-1257, 2005.

GONÇALVES, F. G.; ZANINI, S. R.; GUERRA, A. F. Q. G.; GONÇALVES, E. P.; COLNAGO, G. L.; FEITOSA, M. L. Utilização de pimenta rosa como um aditivo natural na dieta sobre o desempenho de frangos de corte. Revista Brasileira de Saúde e Produção Animal, Salvador, v. 15, n. 1, p. 28-38, 2014.

HARIKISHORE, K.; SESHAIAH, K.; REDDY, A.; RAO, M.; WANG, M. Biosorption of $\mathrm{Pb} 2+$ from aqueous solutions by Moringa oleifera bark: Equilibrium and kinetic studies. Journal of Hazardous Materials, Amsterdam, v. 174, p. 831-838, 2010.

LUNA, L. G. Manual of the histologic staining methods of the Armed Forces Institute of Pathology. $3^{\text {th }}$ ed. New York : McGraw Hill, 1968. 258 p.

MACARI, M.; FURLAN, R. L.; GONZALES, L. Fisiologia aviária aplicada a frangos de corte. Jaboticabal: FUNEP/UNESP, 2002. 37 5p.

MARENGONI, N. G.; KLOSOWSKI, E. S.; OLIVEIRA, K. P.; CHAMBO, A. P. S.; GONÇALVES JUNIOR, A. C. Bioacumulação de metais pesados e nutrientes no mexilhão dourado do reservatório da usina hidrelétrica de Itaipu binacional. Química Nova, São Paulo, v. 36, n. 3, p. 359-363, 2013.

MELLO, H. H. D. C.; GOMES, P. C.; ROSTAGNO, H. S.; ALBINO, L. F. T.; OLIVEIRA, R. F. M.; ROCHA, T. C.; RIBEIRO, C. L. N. Requirement of available phosphorus by female broiler chickens keeping the calcium: available phosphorus ratio at 2:1. Revista Brasileira de Zootecnia, Viçosa, MG, v. 41, n. 11, p. 2329-2335, 2012.

MELO, T. V.; MOURA, A. M. A. Utilização da farinha de algas calcárias na alimentação animal. Archivos de Zootecnia, Córdoba, v.58, n.1, p. 87-98, 2009.

MOYLE, J. R.; BURKE, J. M.; FANATICO, A.; MOSJIDIS, J. A.; SPENCER, T.; ARSI, K.; REYESHERRERA, I.; WOO-MING, A.; DONOGHUE, D. J.; DONOGHUE, A. M. Palatability of tannin-rich sericea lespedeza fed to broilers. The Journal of Applied Poultry Research, Champaigh, v. 21, n. 4, p. 891-896, 2012.
NELSON, D. L.; COX, M. M. Lehninger principles of biochemistry. New York: W. H. Freeman, 2008. 1158 p.

NYAMAMBI, B.; NDLOVU, L. R.; NAYK, Y. S.; KOCK, N. D. Intestinal growth and function of broiler chicks fed sorghum based diets differing in condensed tannin levels. South African Journal of Animal Science, Pretoria, v. 37 , n. 3, p. 202-214, 2007.

PINTO, S.; BARROS, C. S.; SLOMP, M. N.; LÁZZARO, R.; COSTA, L. F.; BRUNO, L. D. G. Cálcio e fósforo na dieta de galinhas de postura: uma revisão. Scientia Agraria Paranaenis, Marechal Cândido Rondon, v. 11, n. 1, p. 5-18, 2012.

SAKOMURA, N. K.; ROSTAGNO, H. S. Métodos de pesquisa em nutrição de monogástricos. Jaboticabal: FUNEP, 2007. 283 p.

SAKOMURA, N. K.; VILAR DA SILVA, J. H.; PERAZZOCOSTA, F. G.; FERNANDES, J. B. K.; HAUSCHILD, L. Nutrição de não-ruminantes. Jaboticabal: FUNEP, 2014. 678 p.

SILVA FERNANDES, A. L. da; PEIXOTO, R. R. Avaliação de calcários dolomíticos como fontes de cálcio para frangos de corte em crescimento. Revista Brasileira de Zootecnia, Viçosa, MG, v. 29, n. 6, p. 2260-2267, 2000 .

SILVA, D. J.; QUEIROZ, A. C. Análise de alimentos: métodos químicos e biológicos. 3. ed. Viçosa, MG: Universidade Federal de Viçosa, 2006. 235 p.

SILVA, N.; JUNQUEIRA, V. C. A.; SILVEIRA, N. F. A. Manual de métodos de análise microbiológica de alimentos. São Paulo: Varala, 1997. 295 p.

TORRES, K. A. A.; PIZAURO, J. M.; SOARES, C. P.; SIlvA, T. G.; NOGUEIRA, W. C.; CAMPOS, D. M.; FURLAN, R. L.; MACARI, M. Effects of corn replacement by sorghum in broiler diets on performance and intestinal mucosa integrity. Poultry Science, Savoy, v. 92, n. 6, p. 1564-1571, 2013.

UNIVERSIDADE FEDERAL DE VIÇOSA - UFV. Manual de utilização do programa SAEG: sistema para análise estatísticas e genéticas. Viçosa: Universidade Federal de Viçosa, 1999. 59 p. 